\title{
Pengaruh Metode Problem Based Learning Berbantu Media Puzzle Bangun Datar 3 Dimensi Terhadap Kemamuan Pemechan Masalah
}

\author{
Peni Mardiana Sari ${ }^{1 *}$, Iin Purnamasari ${ }^{2}$, Sunan Baedowi ${ }^{3}$ \\ 1,2,3 Universitas PGRI Semarang
}

\section{A R T I C L E I N F O}

\section{Article history:}

Received 19 August 2018 Received in revised form 19 September 2018 Accepted 20 Oktober 2018

Available online 24

November 2018

\section{Kata Kunci:}

metode PBL, media puzzle bangun datar 3 dimensi, kemampuan pemecahan masalah

Keywords:

PBL method, 3-dimensional flat-build puzzle media problem solving skill.

\begin{abstract}
A B S T R A K
Penelitian ini bertujuan untuk mengetahui pengaruh metode Problem Based Learning Berbantu Media Puzzle Bangun Datar 3 Dimensi berpengaruh terhadap kemampuan memecahkan masalah pada mata pelajaran matematika siswa kelas III SDN Kradenan 01 Pekalongan. Jenis Desain penelitian ini menggunakan True Eksperimental Designs bentuk Pretest-Posttest Control Group Design. Populasi dalam penelitian ini adalah seluruh siswa kelas III SD Negeri Kradenan 01 Pekalongan. Dari hasil analisis statistik dengan uji korelasi diperoleh $r_{\text {hitung }}=0,818$. dan $r_{\text {tabel }}=0,450$ dengan $N=20$, sehingga diperoleh $r_{\text {hitung }}>r_{\text {tabel }}$ yaitu $0,818>0,450 \mathrm{H}_{\mathrm{a}}$ diterima. Dapat disimpulkan bahwa ada pengaruh metode problem based learning berbantu media puzzle bangun datar 3 dimensi terhadap kemampuan pemecahan masalah kelas eksperimen lebih baik dari kelas kontrol. Dilakukan uji regresi untuk melihat seberapa besar pengaruh afektif (sikap) siswa terhadap kemampuan pemecahan masalah siswa sebesar $67 \%$.
\end{abstract}

\section{A B S T R A C T}

This study aims to determine the effect of Problem Based Learning method 3-dimensional flat-build media puzzle effect on the ability to solve problems in mathematics subject class students III SDN Kradenan 01 Pekalongan. This research design uses True Experimental Designs form PretestPosttest Control Group Design. The population in this study is all students of class III SD Negeri Kradenan 01 Pekalongan. Statiscal analysis data results with correlation tests were obtained $r_{\text {hitung }}=$ 0,818 and $r_{\text {tabel }}=0,450$ with $\mathrm{N}=20$, so it is obtained $r_{\text {hitung }}>r_{\text {tabel }}$ yaitu $0,818>0,450 \mathrm{H}_{a}$ accepted. It can be concluded that there is an influence of problem based learning method with 3 dimensional flat-build puzzle media on experimental class problem solving abilities more that control class.redrresio test was conducted to see how much ifluence the affective aspects of students had on students poblem solving abilities obtained $67 \%$.

\footnotetext{
* Corresponding author.

E-mail addresses: penimardianasari@yahoo.com (Peni Mardiana Sari)
} 


\section{Pendahuluan}

Undang -undang Republik Indonesia Nomor 20 tahun 2003 menyebutkan bahwa "Pendidikan adalah usaha sadar dan terencana untuk mewujudkan suasana belajar dan proses pembelajaran agar peserta didik secara aktif mengembangkan potensi dirinya untuk memiliki kekuatan spiritual, keagamaan, pengendalian diri, kepribadian, kecerdasan, akhlak mulia, serta keterampilan yang diperlukan dirinya, masyarakat, bangsa , dan negara".

Berdasarkan kutipan di atas, pendidikan dilakukan dengan kesedaran dan terencana salah satunya adalah untuk mengembangkan potensi dari siswa bagi bangsa dan negara. Pendidikan di sekolah dilaksanakan melalui proses pembelajaran dengan mengikuti kurikulum yang berlaku. Salah satunya terdapat pada mata pelajaran Matematika berasal dari akar kata mathema artinya pengetahuan mathanein artinya berpikir atau belajar. Dalam kamus Bahasa Indonesia diartikan matematika adalah ilmu tentang bilangan hubungan antara bilangan dan prosedur oprasional yang digunakan dalam penyelesaian masalah mengenal bilangan (Depdiknas).

Matematika merupakan salah satu bidang studi yang diajarkan di SD. Matematika dianggap sebagai mata pelajaran yang sulit sehingga kurang diminati (Giarti, 2014: 13-27). Menurut Supriyanto (2014) menyatakan bahwa matematika berfungsi mengembangkan kemampuan menghitung, mengukur, menemukan dan menggunakan rumus matematika yang dapat menunjang pemahaman konsep siswa kaitannya dalam kehidupan sehari-hari. Seorang guru SD yang akan mengajarkan matematika kepada siswanya, hendaklah mengetahui dan memahami objek yang akan diajarkan, yaitu matematika. Karso (2014: 1.39) matematika adalah pola berpikir, pola menggorganisasikan, pembuktian yang logis, matematika itu adalah bahasa yang menggunakan istilah yang didefinisikan dengan cermat, jelas dan akurat representasinya dengan simbul dan padat, lebih berupa bahasa simbol mengenai ide dari pada bunyi. Sedangkan menurut Susanto (2013: 183) "matematika merupakan ide-ide abstrak yang berisi simbol-simbol, maka konsep-konsep matematika harus dipahami terlebih dahulu sebelum mamnipulasi simbol-simbol itu".Berdasarkan dari beberapa pendapat matematika merupakan suatu ilmu yang berhubungan. Mempelajari matematika adalah penting karena dalam kehidupan sehari-hari, kita tidak boleh mengelak dari aplikasi matematika bukan itu saja matematika juga mampu mengembangkan kesadaran tentang nilai-nilai yang secara esensial (Flora Siagian, 2012).

Berdasarkan wawancara dan observasi pada tanggal 30 november 2017 dengan guru kelas III SDN Kradenan 01ibu Misrcochah, S.Pd.,SD masih terkait permasalahan dalam pebelajaran matematika khususnya pada materi luas dan kelilng bangun persegi dan persegi panjang, salah satunya adalah rendanya kemampuan pemecahan masalah. Rendahnya kemampuan pemecahan masalah ada beberapa faktor diantaranya proses pembelajaran belum menggunakan model atau mtode pembelajaran yang inovatif, guru masih menggunkan model pembelajaran konvensional. Hal tersebut menjadikan nilai belajar matematika saat UTS sebagian besar masih rendah, dapat dilihat dari Tabel dibawah ini:

Tabel 1. Persentase Nilai UTS Mata Pelajaran Matematika

\begin{tabular}{cccccc}
\hline Jumlah Siswa & KKM & Mencapai KKM & Persen & $\begin{array}{c}\text { Belum Mencapai } \\
\text { KKM }\end{array}$ & Persen \\
\hline 20 & 10 siswa & 10 siswa & $50 \%$ & 10 & $50 \%$ \\
\hline
\end{tabular}

Agar memperoleh hasil dan proses yang maksimal maka guru harus dapat memecahkan masalah yang terjadi pada materi luas dan keliling bangun persegi dan persegi panjang. Kemampuan pemecahan masalah merupakan salah satu kemampuan dasar matematika yang perlu dimiliki oleh siswa. Lemahnya penguasaan konsep dan prinsip oleh siswa, dapat mengakibatkan kemampuan siswa dalam pemecahan masalah lemah juga.

Menurut Roebyanto (2017: 6) Pemecahan masalah terdapat masalah yang bersifat rutin dan tidak rutin. Soal rutin biasanya mencangkup aplikasi suatu prosedur matematika yang sama atau mirip dengan hal yang baru di pelajari. Sedangkan dalam masalah tidak rutin, untuk sampai pada prosedur yang benar diperlukan pemikiran yang lebih mendalam. Menurut hasil The National Assesment di Amerika Serikat mengindikasikan bahwa siswa SD pada umumnya menghadapi kesulitan dalam menghadapi soal rutin yang memerlukan analisis dan proses berpikir mendalam. Menurut Edwards dan Hummer (2011) model berbasis masalah merupakan model pembelajaran yang memfokuskan hubungan antara teori dengan praktek. Model pembelajaran PBL yaitu sebagai lingkungan pembelajaran dengan berbasis pada masalah (Tan dalam Rusman, 2011: 229). Model PBL adalah pembelajaran berbasis masalah yang mengoptimalkan kemampuan berpikir siswa melalui proses kerja kelompok yang sistematis (Putra, 2013: 65). Sehingga untuk memberikan keaktifan dalam proses pembelajaran pada saat pengimplementasian multimedia 
interaktif model PBL disertakan. Langkah-langkah model PBL berlangsung dengan beberapa tahap menurut Dwi, dkk (2013: 11) yaitu: 1) Orientasi peserta didik pada masalah, 2) Mengorganisasikan peserta didik untuk belajar, 3) Membantu penyelidikan mandiri dan kelompok, 4) Mengembangkan dan menyajikan hasil karya, 5) Menganalisis dan mengevaluasi proses pemecahan masalah.

Lebih lanjut, keampuan model PBL ini didukung oleh penelitian yang terdahulu. Hanafi Maarif \& Wahyudi (2015) dalam penelitianannya yang berjudul Eksperimentasi Problem Based Learning Dan CIRC Dalam Menyelesaikan Soal Cerita Matematika Siswa Kelas 5 SD. Penelitian lainnya yang telah di lakukan terdahulu dari model Discovery Learning. Wahyudi \& Mia Christy Siswanti (2015) dengan judul Pengaruh Pendekatan Saintifik Melalui Model Discovery Learning Dengan Permainan Terhadap Hasil Belajar Matematika Siswa Kelas 5 SD. Serta penelitian yang telah dilakukan oleh Puspita Indah Rahayu, Undang Rosidin, Abdurrahman. (2015). Perbandingan Hasil Belajar Siswa Antara Pembelajaran Menggunakan PBL Dan Discovery Learning.

Tabel 2. Sintak atau lankah-langkahProblem Based Learning

\begin{tabular}{ll}
\hline Tahap & Aktifitas Guru dan Peserta didik \\
\hline Tahap 1 & \multicolumn{1}{c}{2} \\
$\begin{array}{l}\text { Mengorientasikan peserta } \\
\text { didik terhadap masalah }\end{array}$ & $\begin{array}{l}\text { Guru menjelaskan tujuan pembelajaran dan sarana atau logistik yang } \\
\text { dibutuhkan. Guru memotivasi peserta didik untuk terlibat dalam aktivitas } \\
\text { pemecahan masalah nyata yang dipilih atau di tentukan. }\end{array}$ \\
$\begin{array}{l}\text { Mengorganisasi peserta } \\
\text { didik untuk belajar }\end{array}$ & $\begin{array}{l}\text { Guru membantu peserta didik mendefinisikan dan mengorganisasi tugas } \\
\text { belajar yang berhubungan dengan masalah yang sudah diorientasikan } \\
\text { pada tahap sebelumnya. }\end{array}$ \\
$\begin{array}{l}\text { Membimbing } \\
\text { penyelidikan individual } \\
\text { maupun kelompok }\end{array}$ & $\begin{array}{l}\text { Guru mendorong peserta didik untuk mengumpulkan informasi yang } \\
\text { sesuai dengan melaksanakan eksperimen untuk mendapatkan kejelasan }\end{array}$ \\
Menap 4 & Gangerlukan untuk menyelesaikan masalah. \\
menyajikangkan hasil karya & Guru membantu peserta didik untuk bebagi tugas dan merencanakan atau \\
& menyiapkan karya yang sesuai sebagai hasil pemecahan masalah dalam \\
\end{tabular}

(Fathurrohman, 2015: 116)

Penggunaan media puzzle dapat melahirkan suasana yang menyenangkan dalam proses belajar anak. Adanya teka-teki untuk memecahkan masalah dengan anak menyusun potongan-potongan kotak persegi bila siswa menyusun dengan benar bagian ditengah-tengah akan ada gambar bangun datar. Media puzzle ini membuat anak tidak merasa bosan, karena anak suka jenuh apabila seorang pendidik hanya menerangkan dalam bentuk tulisan dan penggunaan media berupa buku saja. Hal ini dikarenakan pada usia anak-anak sangat peka terhadap rangsangan yang diterima dari lingkungan. Rasa ingin tahunya yang tinggi akan tersalurkan apabila mendapatkan rangsangan yang sesuai dengan tugas perkembangannya. Ini diyakini akan berhasil mamacu anak untuk mempelajari sesuatu dengan minat, kebutuhan dan kemampuannya.

\section{Metode}

Penelitian ini menggunakan True Eksperimental Designs bentuk Pretest-Posttest Control Group Design. Populasi dalam penelitian ini adalah seluruh siswa kelas III SD Negeri 01 Kradenan yang terdiri dari dua kelas yaitu kelas IVA dan IVB berjumlah 40 siswa . sampel yang digunakan dalam penelitian ini adalah siswa-siswi kelas IVA dan IVB yang masing-masing kelas berjumlah 20 siswa.. jadi dalam penelitian ini jumlah sampel yang digunakan adalah semua anggota populasi yang terdiri dari dua kelas yang masing-masing kelas terdiri dari 20 siswa kelas IVA dan IVB SD Negeri Kradenan 01 Pekalongan.

Teknik pengumpulan data dalam penelitian ini yaitu teknik tes dan nontes. Tes yang dilakukan dalam penelitian ini dibagi menjadi dua yaitu pretest dan posttest. Teknik nontes yang digunakan dalam penelitian ini adalah observasi, wawancara, dokumentasi. Data hasil belajar Matematika dikumpulkan dengan instrumen tes berbentuk pilihan essay berjumlah 25 butir soal. Sebelum digunakan dalam penelitian, instrumen penelitian terlebih dulu dilakukan uji coba soal. Uji coba atau validitas instrumen dilakukan untuk memperoleh gambaran kalayakan dari instrumen yang akan digunakan dalam penelitian. 
Terdapat beberapa langkah validasi terhadap instrumen meliputi validitas butir tes, analisis daya beda, analisis tingkat kesukaran butir, dan analisis reliabilitas.

Data yang dikumpulkan selanjutnya dilakukan pengujian hipotesis menggunakan uji korelasi. Sebelum dilakukan pengujian hipotesis terlebih dahulu dilakukan uji normalitas dan uji homogenitas.

\section{Hasil dan pembahasan}

Data penelitian ini terdiri dari data pretest dan posttest kelas eksperimen dan kelas kontrol. Berikut data nilai pretest dan posttest SD Negeri 01 Menganti Jepara yang disajikan dalam bentuk tabel:

\section{Hasil Pretest dan Posttest}

Tabel 3. Nilai Pretest Kelas Kontrol dan Eksperimen

\begin{tabular}{lll}
\hline \multicolumn{1}{c}{ Keterangan } & \multicolumn{1}{c}{ Model Konvensional } & Metode Problem Based Learning \\
\hline Nilai Tertinggi & 80 & 84 \\
Nilai Terendah & 37 & 44 \\
& & 66,7 \\
Rata-rata & 59,55 & 20 \\
Jumlah siswa & 20 & 20 \\
\hline
\end{tabular}

Tabel 4. Nilai Posttest Kelas Eksperimen dan Kelas Kontrol

\begin{tabular}{lll}
\hline \multicolumn{1}{c}{ Keterangan } & \multicolumn{1}{c}{ Model Konvensional } & Metode Problem Based Learning \\
\hline Nilai Tertinggi & 83 & 92 \\
Nilai Terendah & 50 & 58 \\
Rata-rata & 72,7 & 80,60 \\
Jumlah siswa & 20 & 20 \\
\hline
\end{tabular}

Berdasarkan tabel 3 dan tabel 4 di atas dapat dilihat bahwa selisih nilai pretest pada kelas eksperimen dan kelas kontrol untuk nilai terendahnya yaitu 37 dan kelas eksperimen 44 dan nilai tertinggi pada kelas kontrol yaitu 80 sedangkan kelas kontrol 84 dengan masing-masing rata-rata yang hampir sama yaitu 59,55 dan 66,7. Sedangkan untuk nilai posttest terendah pada kelas eskperimen yaitu 58 dan kelas kontrol 50 , nilai tertinggi pada kelas eksperimen yaitu 92 dan kelas kontrol 83 dengan masing-masing rata rata yang berbeda jauh yaitu kelas eksperimen 80,60 dan kelas kontrol 72,7. Hal tersebut menunjukkan bahwa terdapat peningkatan dari nilai pretest yang sebelum diberikan perlakuan dengan nilai posttest yang sudah diberikan perlakuan dengan metode Problem Based Learning berbantu media puzzle bangun datar dimensi.

2. Hasil Nilai Aspek Afektif Kelas Kontrol dan Eksperimen

Tabel 5. Data Nilai Aspek Afektif Kelas Kontrol

\begin{tabular}{cccc}
\hline Pertemuan ke & Nilai Tertinggi & Nilai Terendah & Nili Afektif \\
\hline 1 & 83 & 40 & 67,5 \\
2 & 83 & 56 & 73,75 \\
& Total rata-rata & & 70,62 \\
\hline
\end{tabular}

Sumber : Data Hasil Penelitian 2018

Nilai aspek afektik yang di peroleh kelas kontrol pada pertemuan ke 1 nilai tertinggi mencapai 83 dan nilai teredahnya yaitu 40 dengan total rata-rata pada pertemuan ke 1 67,5. Pada pertemun ke 2 nilai tertigg pada kelas kontrol mecapai 83 dan nilai terendah yaitu 56 dengan total nilai afektik 73,75. Hal ini menunjukkan bahwa nilai aspek afektik pada pertemuan ke 1 dan pertemuan ke 2 mencapai total ratarata 70,62 . 
Tabel 6. Data Nilai Aspek Afektif Kelas eksperimen

\begin{tabular}{cccc}
\hline Pertemuan ke & Nilai Tertinggi & Nilai Terendah & Nilai afektif \\
\hline 1 & 83 & 58 & 71 \\
2 & 92 & 75 & 86 \\
& Total rata-rata & & 78,5 \\
\hline
\end{tabular}

Sumber : Data Hasil Penelitian 2018

Nilai aspek afektik yang di peroleh kelas eksperimenl pada pertemuan ke 1 nilai tertinggi mencapai 83 dan nilai teredahnya yaitu 58 dengan total rata-rata pada pertemuan ke 171 . Pada pertemun ke 2 nilai tertinggi pada kelas eksperime mecapai 92 dan nilai terendah yaitu 75 dengan total nilai afektik 86 . Hal ini menunjukkan bahwa nilai aspek afektik pada pertemuan ke 1 dan pertemuan ke 2 mencapai total ratarata 78,5 .

Jadi dapat disimpulkan bahwa nilai sikap pada kelas kontrol dengan pembelajaran konvensionl memiliki total rata-rata 70 sedangkan nilai afektif kelas eksperimen dengan metode pembelajaran problem based learning berbantu media puzzle bangun datar 3 dimensi memiliki total nilai rata-rata 78,5

2. Uji Normalitas

Uji Normalitas Data Awal

Tabel 7. Daftar Uji Normalitas Nilai Pretest

\begin{tabular}{cccc}
\hline Nilai & $\mathrm{L}_{0}$ & $\mathrm{~L}_{\text {tabel }}$ & Keterangan \\
\hline $\begin{array}{c}\text { Pretestkelas kontrol } \\
\text { Pretest kelas }\end{array}$ & 0,119 & 0,190 & Berdistribusi normal \\
eksperimen & 0,067 & 0190 & Berdistribusi normal \\
\hline
\end{tabular}

Sumber: Data Hasil Penelitian 2018

Berdasarkan Tabel 7 menunjukkan bahwa populasi dari kedua kelas berasal dari data yang berdisribusi normal dengan Lhitung pada kelas konvensional sebesar 0,119, Lhitung pada kelas eksperimensebesar 0,067. Karena $\mathrm{L}_{\text {tabel }}>\mathrm{L}_{\text {tabel }}$ dengan menggunakan taraf signifikasi sebesar $5 \%$.

Uji Normalitas Akhir

Tabel 8. Daftar Uji Normalitas Nilai postest

\begin{tabular}{cccc}
\hline Nilai & $\mathrm{L}_{0}$ & $\mathrm{~L}_{\text {tabel }}$ & Keterangan \\
\hline $\begin{array}{c}\text { Postest kelas kontrol } \\
\text { Postest kelas }\end{array}$ & 0,128 & 0,190 & Berdistribusi normal \\
eksperimen & 0,140 & 0190 & Berdistribusi normal \\
\hline
\end{tabular}

Sumber: Data Hasil Penelitian 2018

Berdasarkan Tabel 8 menunjukkan bahwa populasi dari kedua kelas berasal dari data yang berdisribusi normal dengan $L_{\text {hitung }}$ pada kelas konvensional sebesar 0,128, L Litung pada kelas eksperimen sebesar 0,140. Karena $\mathrm{L}_{\text {tabel }}>\mathrm{L}_{\text {tabel }}$ dengan menggunakan taraf signifikasi sebesar $5 \%$.

\section{Homogenitas}

Tabel 9. Uji Homogenitas

\begin{tabular}{lcll}
\hline Homogenitas & $f_{\text {tabel }}$ & $f_{\text {hitung }}$ & Keterangan \\
\hline (Pretest) & 2,17 & 1,24 & Homogen \\
Akhir (Posttest) & 2,17 & 2,07 & Homogen \\
\hline
\end{tabular}

Berdasarkan hasil perhitungan dengan $\alpha=5 \%$ dan $\mathrm{dk}=19$ diperoleh dari pretestnilai $f_{\text {hitung }}=1,24$ dengan $f$ tabel $=2,17$. Karena $f$ hitung $<f$ tabel $=1,24<2,17$ maka $\mathrm{H}_{0}$ diterima, sedangkan dari postetsnilai $f$ hitung $=20,7$ dengan $f$ tabel $=2,17$. Karena $f_{\text {hitung }}<f$ tabel $=2,07<2,17$ maka $\mathrm{H}_{0}$ diterima Jadi dapat disimpulkan bahwa kedua sampel yang menggunakan metode pembelajaran konvensional, metode Problem Based 
Learning berasal dari populasi yang sama atau homogen. Perhitungan uji homogenitas selengkapnya dapat dilihat pada Lampiran.

4. Uji Regesi Linier Sederhana

Tabel 10. Hasil Analisis persamaan Regresi Linier Sederhana

\begin{tabular}{cccc}
\hline Kelas & A & B & Persamaan Regresi \\
\hline Eksperimen & $-53,608$ & 1,674 & Y $=-53,608+1,674 \mathrm{X}$ \\
\hline
\end{tabular}

Setelah melakukan analisis persamaan regresi linier sederhana selanjutnya melakukan uji Linieritas, maka diperoleh data sebagai berikut

Tabel 11. Uji Linieritas

\begin{tabular}{ccccc}
\hline Kelas & JKt & JKa & JKb & JKres \\
\hline & 132046 & 129927,2 & 1420,280 & 689,519 \\
Eksperimen & JKg & JKtc & DBg & DBtc \\
& 355,666 & 342,852 & 13 & 5 \\
& Rtc & RKg & F & F tabel \\
& 68,570 & 27,358 & 2,506 & 3,03 \\
\hline
\end{tabular}

Berdasarkan tabel 11 di atas diperoleh Fhitung=2,506 dengan $n=20$ dan taraf nyata $\alpha=0,05$, dari Fhitung didapat $\mathrm{F}_{\text {tabel }}=3.03$. Karena Fhitung $<\mathrm{F}_{\text {tabel }}$ yaitu $1,734<3,11$, maka $\mathrm{H}_{0}$ diterima sehingga dapat disimpulkan bahwa persamaan linier. Selanjutnya dilakukan uji signifikansi dan didapat data sebagai berikut:

Tabel 12. Hasil Uji Signifikansi

\begin{tabular}{|c|c|c|c|c|}
\hline Kelas & JKreg & JKres & DBreg & DBres \\
\hline \multirow{3}{*}{ Eksperimen } & 131122 & 924 & 1 & 18 \\
\hline & RKreg & RKres & Freg & $\mathrm{F}_{\text {tabel }}$ \\
\hline & 131122 & 51,347 & 2553,66 & 4,41 \\
\hline
\end{tabular}

Berdasarkan tabel 12 di atas diperoleh Fhitung= 2553,66 dengan $n=20$ dan taraf nyata $\alpha=5 \%$, dari Fhitung didapat $F_{\text {tabel }}=4,41$. Karena Fhitung $>F_{\text {tabel }}$ yaitu 2553,66> 4,11, maka $\mathrm{H}_{0}$ ditolak sehingga dapat disimpulkan bahwa persamaan regresi signifikan.

\section{Koefisien Determinasi}

Besarnya pengaruh variabel keaktifan siswa dengan variabel hasil belajar siswa dapat dilihat pada koefisien determinasinya. Koefisien determinasi diperoleh menggunakan rumus:

$$
r^{2}=\frac{b\left\{n \sum X_{i} Y_{i}-\left(\sum X_{i}\right)\left(\sum Y_{i}\right)\right.}{n \sum Y_{i}^{2}-\left(\sum Y_{i}\right)^{2}}
$$

Berdasarkan hasil penghitungan yang dapat dilihat pada lampiran Uji Linier Sederhana, diperoleh nilai $r^{2}=0,751602228 \mathrm{Hal}$ ini berarti ada pengaruh psikomotorik (penggunaan media Puzzle bangun datar 3 dimensi) siswa terhadap kemampuan pemecahan masaah siswa sebesar 67\%, sedangkan 33\% dipengaruhi oleh faktor yang lain.

\section{Hipotesis Statistik}

Hipotesis yang akan diajukan dalam penelitian ini, dirumuskan sebagai berikut:

$\mathrm{H}_{0}$ : pengaruh metode problem based learning berbantu media puzzle bangun datar 3 dimensi terhadap kemampuan pemecahan masalah kelas eksperimen tidak lebih baik dari kelas kontrol

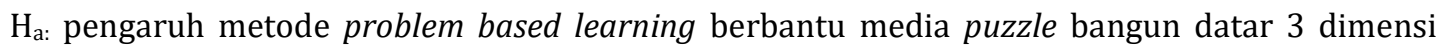
terhadap kemampuan pemecahan masalah kelas eksperimen lebih baik dari kelas kontrol Berdasarkan perhitungan uji korelasi pada lampiran 60 diperoleh data sebagai berikut: 
Tabel 13. Kolerasi persepsi siswa dengan motivasi belajar

\begin{tabular}{ll}
\hline & \multicolumn{1}{c}{ Kolerasi } \\
\hline$r_{\text {hitung }}$ & 0,818 \\
$r_{\text {tabel }}$ & 0,450 \\
Kesimpulan & Ada korelasi antara metode problem based learning terhadap \\
& kemampuan pemecahan masalah \\
\hline
\end{tabular}

Berdasarkan tabel 13 diatas diperoleh $r_{\text {hitung }}=0,818$. Selanjutnya $r_{\text {hitung }}$ tersebut dibandingkan dengan $r_{\text {tabel }}=0,450$ taraf signifikan $\alpha=5 \%$ dengan $N=20$, sehingga diperoleh $r_{\text {hitung }}>r_{\text {tabel }}$ yaitu 0,818 $>0,450$. Dengan demikian $\mathrm{H}_{a}$ diterima dan $\mathrm{H}_{0}$ ditolak. Dapat disimpulkan bahwa ada pengaruh metode problem based learning berbantu media puzzle bangun datar 3 dimensi terhadap kemampuan pemecahan masalah kelas eksperimen lebih baik dari kelas kontrol

Berdasarkan perhitungan analisis statistik pada paparan di atas, maka di dalam pembahasan ini akan dijelaskan mengenai hasil dari analisis data. Pada penelitian ini, peneliti menggunakan desain penelitian Pre-Experimental Design dengan bentuk Pretest-Posttest Design Control Grup Design. Peneliti menggunakan instrumen tes berupa soal essay, untuk menentukan soal yang akan dilakukan uji validitas, uji reliabilitas, taraf kesukaran dan daya pembeda. Pengambilan sampel ini didasarkan pada kelas yang berdistribusi normal. Penelitian ini dilakukan terhadap siswa kelas IIIA dan IIIB SDN Kradenan 01 Kota Pekalongan dengan jumlah 20 siswa.

Pada tahap sebelum diberi perlakuan, terlebih dahulu dilakukan uji normalitas awal dengan menggunakan pretest. Uji normalitas dilakukan untuk mengetahui subjek penelitian berdistribusi normal atau tidak normal.

Berdasarkan perhitungan nilai pretest kelas kontrol yang dilakukan diperoleh kesimpulan bahwa kelas IIIASDN Kradenan 01 pekalongan berdistribusi normal karena nilai $L_{0}<L_{\text {tabel }}$ yaitu $0,119<$ 0,190 dengan $\mathrm{n}=20$ dan taraf nyata $\alpha=0,05$. Sedangkan pretest kelas eksperimen yang diperoleh kesimpulan bahwa kelas IIIB SDN Kradenan 01 pekalongan berdistribusi normal karena nilai $L_{0}<L_{\text {tabel }}$ yaitu $0,067<0,190$ dengan $\mathrm{n}=20$ dan taraf nyata $\alpha=0,05$.Pada tahap akhir berikutnya dilakukan kembali uji normalitas dengan menggunakan nilai posttest. Berdasarkan perhitunganposttest kelas kontrol diperoleh $\mathrm{L}_{0}=0,128$ dengan $\mathrm{n}=20$ dan taraf nyata $\alpha=0,05$, dari daftar nilai kritis $\mathrm{L}$ didapat $\mathrm{L}_{\text {tabel }}=0,190$. Karena $L_{0}<L_{\text {tabel }}$ yaitu $0,128<0,10$, maka $H_{0}$ diterima sehingga dapat disimpulkan bahwa sampel berasal dari populasi berdistribusi normal. Sedangkan posttest kelas eksperimen diperoleh $\mathrm{L}_{\mathrm{o}}=0,140$ dengan $\mathrm{n}=20$ dan taraf nyata $\alpha=0,05$, dari daftar nilai kritis $\mathrm{L}$ didapat $\mathrm{L}_{\text {tabel }}=0,190$. Karena $L_{0}<L_{\text {tabel }}$ yaitu $0,140<0,190$, maka $H_{0}$ diterima sehingga dapat disimpulkan bahwa sampel berasal dari populasi berdistribusi normal.

Setelah dilakukannya uji normalitas, dilanjutkan dengan uji homogenitas untuk mengetahui kesamaan rata-rata dua kelompok, pada tahap awal yaitu uji homogenitas Berdasarkan hasil perhitungan dengan $\alpha=5 \%$ dan dk=19 diperoleh dari pretestnilai $f_{\text {hitung }}=1,24$ dengan $f_{\text {tabel }}=2,17$. Karena $f_{\text {hitung }}<f_{\text {tabel }}=$ $1,24<2,17$ maka $\mathrm{H}_{0}$ diterima, sedangkan dari postetsnilai $f_{\text {hitung }}=20,7$ dengan $f_{\text {tabel }}=2,17$. Karena $f_{\text {hitung }}<f$ tabel $=2,07<2,17$ maka $\mathrm{H}_{0}$ diterima Jadi dapat disimpulkan bahwa kedua sampel yang menggunakan metode pembelajaran konvensional, metode Problem Based Learning berasal dari populasi yang sama atau homogen.

Selain nilai pretest dan posttest yang nantinya digunakan sebagai nilai aspek kognitif dengan aspek 3 indikator yang dilihat yaitu aktif, sungguh-sungguh, kerjasama. Berdasarkan perhitungan, tampak perbedaan rata-rata nilai aspek afektif kelas kontrolpertemuan ke-1yaitu 67,5, pertemuan ke- 2 yaitu 73 kelas IIIA SDN Kradenan 01 Pekalongan. Sedangkan rata-rata nilai afektif pada kelas eksperimen pertemuan ke -1 yaitu 71, pertemuan ke -2 yaitu 86 kelas IIIB SDN Kradenan 01 Pekalongan.

Uji regresi linier sederhana digunakan untuk mengetahui adanya pengaruh dan seberapa besar pengaruh antara keaktifan (sikap) siswa dalam menggunakan perlakuan dengan metode problem based learning berbantu media puzzle bangun datar 3 dimensi dengan kemampuan pemecahan amaslah siswa yang di abil dari nilai hasil belajar siswa setelah posttest. Persamaan regresi yang diperoleh adalah $\hat{Y}=a+b X=-53,6083+1,674 X$, dapat dilihat bahwa koefisien arah regresi yaitu $b$ bernilai positif sehingga perubahannya bersifat pertambahan, artinya untuk setiap afektif (sikap) siswa bertambah satu satuan maka rata-rata hasil belajar siswa bertambah sebesar 1,674.

Selanjutnya dilakukan pengujian kelinieran persamaan regresi antara pengaruh variabel afektif (sikap) siswa terhadap kemampuan pemecahan masalah siswa, artinya persamaan linier. Selanjtnya dilakukan uji signifikasi $F_{\text {hitung }}>F_{\text {tabel }}$ yaitu 2553,66 $<4,41$ maka di peroleh sehingga $H_{0}$ ditolak 
maka perasamaan regresi signifikan Hal ini berarti pengaruh antara afektif (sikap) siswa dengan kemampua pemecahan maaalah siswa signifikan dengan nilai $r^{2}=0,670137247$ yang artinya pengaruh keaktifan siswa terhadap hasil belajar siswa sebesar $67 \%$ dan $34 \%$ dipengaruhi faktor lainnya.

Berdasarkan pengujian kolerasi diperoleh $r_{\text {hitung }}>r_{\text {tabel }}$ atau 0,818 $>0,450$ sehingga demikian $\mathrm{H}_{\mathrm{a}}$ diterima dan $\mathrm{H}_{0}$ ditolak. Dapat disimpulkan bahwa ada pengaruh metode problem based learning berbantu media puzzle bangun datar 3 dimensi terhadap kemampuan pemecahan masalah kelas eksperimen lebih baik dari kelas kontrol. Serta diperoleh Koefisien determinasi sebesar $67 \%$ yang artinya pengaruh metode problem based lernig terhadap kemampuan pemecahan masalah siswa sebesar $67 \%$ dan $33 \%$ dipengaruhi oleh faktor lain yang tidak diteliti pada penelitian ini.

Hal tersebut dikarenakan siswa terlibat aktif dalam pembelajaran karena adanya metode problem based learning berbantu media puzzle bangun datar 3 dimensi. Metode problem based learningdidasarkan pada teori belajar kontruktivisme. Menurut Trianto (2014:29) menyatakan bahwa teori kontruktivisme yaitu siswa harus menentukan sendiri dan mentransformsikan informasi kompleks. Teori kontruktivisme berkembang dari tokoh Piaget danVygotsky. Dalam hal ini siswa harus benar-benar memahami dan dapat menerpkan pengetahuan dengan tujuan pembelajaran yang dirancang untuk dapat merangsang dan melibatkan pembelajaran dalam pola pemecahn masalah menggunakan masalah nyata (otentik) yang tidak terstruktur (ill-structured)dan bersifat terbuka sebagai konteks bagi peserta didik untuk mengembangkan keterampilan menyelesikan masalah dan berfikir kritis sekaligus membangun pengetahuan baru.

Dengan tujuan pembelajaran yang dirancang untuk dapat meragsang dan melibatkan pembelajaran dalam pola pemechan masalah. kondisi ini akan dapat mengembangkan keahlian belajar dalam bidangnya langsung dalam mengidentifikasi permasalahan dan juga berbantu dengan penggunan media puzzle bangun datar 3 dimensi membuat siswa menjadi antusias dan tidak bosan, hal ini sesuai dengan Al-Azizy dalam Sucahyo jurnal PGSD dalam aertikel yang berudul "Penggunaa Mdia Puzzleuntuk Menngkatkan hasil Belajar di Sekolah Dasar" Vol. 1 No. 2 (2013:2), media puzzle merupakan suatu media pembelajaran berupa potongan-potongangambar yang disusun hingga terbentuk menjadi gambar yang utuh. Pemilihan media puzzle selain menarikdan dapat memusatkan perhatian siswa. yang akan menambah proses pembelajaran akan semain menarik karena dengan menggunakan puzzle siswa dalam pembelajara ikut aktif dan manfaat puzzle bagi anak melatih konsentrasi, kesabaran dan dapat melatih anak berfikir matematik (berfikir menggunakan otak kanan).

\section{Simpulan dan saran}

Berdasarkan rumusan masalah, hipotesis, analisis data penelitian, dan pembahasan, maka diperoleh kesimpulan bahwa;"Terdapat Pengaruh Metode Problem Based Learning Berbantu Media Puzzle Bangun Datar 3 Dimensi Terhadap Kemampuan Pemecahan Masalah Kelas III SDN Kradenan 01 Pekalongan" dengan rincian hasil sebagai berikut:

Setelah dilakukan uji korelasi diperoleh $r_{\text {hitung }}=0,818$. Selanjutnya $r_{\text {hitung }}$ tersebut dibandingkan dengan $r_{\text {tabel }}=0,450$ taraf signifikan $\alpha=5 \%$ dengan $N=20$, sehingga diperoleh $r_{\text {hitung }}>r_{\text {tabel }}$ yaitu 0,818 $>0,450$. Dengan demikian $\mathrm{H}_{a}$ diterima dan $\mathrm{H}_{0}$ ditolak. Dapat disimpulkan bahwa ada pengaruh metode problem based learning berbantu media puzzle bangun datar 3 dimensi terhadap kemampuan pemecahan masalah kelas eksperimen lebih baik dari kelas kontrol.

Setelah dilakukan uji regresi, diperoleh Fhitung $=2553,66$ dengan $n=20$ dan taraf nyata $\alpha=5 \%$, dari Fhitung didapat $\mathrm{F}_{\text {tabel }}=4,41$. Karena Fhitung $>\mathrm{F}_{\text {tabel }}$ yaitu 2553,66 $>4,41$, maka $\mathrm{H}_{0}$ ditolak sehingga dapat disimpulkan bahwa persamaan regresi signifikan. Aspek sikap mempengaruhi kemampuan pemecahan masalah yang diambil dari hasil posttest sebesar $67 \%$. Sehingga terdapat pengaruh metode Problem Based Learning Berbantu Media Puzzle Bangun Datar 3 Dimensi Terhadap Kemampuan Pemecahan Masalah Kelas III SDN Kradenan 01 Pekalongan.

\section{Daftar Rujukan}

Dewantara, D. (2014). Penerapan Model Pembelajaran Problem Based Learning Untuk Meningkatkan Aktivitas Dan Hasil Belajar Siswa Pada Pelajaran IPA (Studi Pada Siswa Kelas V SDN Pengambangan 6 Banjarmasin). Jurnal Paradigma Volume 11 Nomor 2 Juli 2016, 41 - 44.

Edwards, S. dan Hummer, M. (2007). Problem Baseb Learning in Early Chilhood and Primary Pre-Service Teacher Education: Identifying the Issues and Examining the Benefits. Journal Internasional.

Fathurrohman, M. 2015. Model-Model Pembelajaran Inovatif. Jogjakarta: Ar-ruzz media 
Flora Siagian, Roida Eva. 2012. Pengaruh Minat Dan Kebiasaan Belajar Siswa Terrhadap Prestasi Belajar Matematika. Formatif: Jurnal Ilmiah Pendidikan MIPA, Vol. 2, No. 2.

Giarti, Sri. 2014. Peningkatan Keterampilan Proses Pemecahan Masalah dan Hasil Belajar Matematika Menggunakan Model PBL Terintegrasi Penilaian Autentik pada Siswa Kelas VI SDN 2 Bengle Wonosegoro. Scholaria. 4 (3), 13-27.

Goenawan, R dan Sri Harmini. 2017. Pemechan Masalah Matematika. Bandung: PT Remaja Rosdakarya

Hajar, Nasaul Azmy, A.Y Djoko Darmono, A,B,C. (2015). Pengaruh Model pembelajaran Problem Based Learning(pbl) Untuk Meningkatkan Hasil Belajar Siswa x-3 Pada Mata Pelajaran Sosiologi sma Negreri Kebakkramat Tahun Pelajaran 2015-2016 Jurnal Ilmiah Pend.Sos Ant, 7 (2)

Henny Dewi Koeswati dkk. (2018). Model Problem Based Learning (PBL) Berbasis Media Interaktif Untuk Meningkatkan Keterampilan Berpikir Kritis dan Hasil Belajar Pada Sub Tema Lingkungan Tempat Tinggalku Kelas 4 SD. Temanggung: UKSW.

Karso.2014. Pendidikan Matematika 1. Tanggerang Selatan : Universitas Terbuka

Maarif, H., \& Wahyudi, W. (2015). Eksperimentasi Problem Based Learning dan CIRC dalam Menyelesaikan Soal Cerita Matematika Siswa Kelas 5 SD. Scholaria: Jurnal Pendidikan dan Kebudayaan, 5(2), 97-115.

Putra, Stitava Rizema. 2013. Desain Belajar Mengajar Kreatif Berbasis Sains. Jogyakarta: Diva Press

Rahayu, P. I., Rosidin, U., \& Abdurrahman, A. (2015). Perbandingan Hasil Belajar Siswa antara Pembelajaran Menggunakan PBL dan Discovery Learning. Jurnal Pembelajaran Fisika, 3(5)

Rahmasari, R. (2016). Penerapan Model Pembelajaran Problem Based Learning Untuk Meningkatkan Hasil Belajar IPA Kelas IV SD. Jurnal Pendidikan Guru Sekolah Dasar Edisi 36 Tahun ke 5 2016, 3456 3465.

Rusman. 2011. Model-Model Pembelajaran. Jakarta: PT. Raja Grafindo Persada.

Susanto, Ahmad. 2013. Teori Belajar \& Pembelajaran di Sekolah Dasar. Jakarta: Prenadamedia Group.

Supriyanto, Bambang. 2014. Penerapan Discovery Learning Untuk Meningkatkan Hasil Belajar Siswa Kelas VI B Mata Pelajaran Matematika Pokok Bahasan Keliling Dan Luas Lingkarandi Sdn Tanggul Wetan 02kecamatan Tanggul Kabupaten Jember. Jurnal Pancara Pendidikan, Vol.3, No.2.

Suwandi, Y. (2015). Peningkatan Hasil Belajar IPA Tentang Ekosistem Melalui Metode Problem Based Learning Pada Siswa Kelas V Sekolah Dasar Kabupaten Tana Tidung. Jurnal Pendidikan Dasar Volume 6 Edisis 1 mei 2015, 93 - 102.

Syafriana, D. (2016). Penerapan Model Problem Based Learning (Pbl) Dalam Pendekatan Saintifik Untuk Meningkatkan Hasil. Jurnal Inovasi Pendidikan Dan Pembelajaran Sekolah Dasar, $30-43$.

Wahyudi, W., \& Siswanti, M. C. (2015). Pengaruh Pendekatan Saintifik Melalui Model Discovery Learning dengan Permainan Terhadap Hasil Belajar Matematika Siswa Kelas 5 SD. Scholaria: Jurnal Pendidikan dan Kebudayaan, 5(3), 23

Wahyudi., Anugraheni, I., \& Adi, w. 2018. Pengembangan Model Blended Learning Berbasis Proyek untuk Menunjang Kreatifitas Mahasiswa Merancang Pembelajaran Matematika Sekolah Dasar. Jurnal Ilmiah Pendidikan Matematika. Vol 6(2). 68-81

Widhiatma, Y. (2017). Penerapan Model Problem Based Learning Untuk Meningkatkan Hasil Belajar IPA Siswa Kelas 4. e-jurnalmitrapendidikan, 451-453. 